\title{
Islam and Democracy. Can They Co-Exist?
}

\author{
Antonello Canzano \\ University "G. d'Annunzio" of Chieti-Pescara, Pescara, Italy \\ Email: a.canzano@unich@unich.it
}

How to cite this paper: Canzano, A. (2019). Islam and Democracy. Can They Co-Exist? Advances in Applied Sociology, 9, 431-445.

https://doi.org/10.4236/aasoci.2019.99032

Received: July 15, 2019

Accepted: September 9, 2019

Published: September 12, 2019

Copyright (c) 2019 by author(s) and Scientific Research Publishing Inc. This work is licensed under the Creative Commons Attribution International License (CC BY 4.0).

http://creativecommons.org/licenses/by/4.0/

\begin{abstract}
In this article one wonders if the union between democracy and Islam is possible and in what form. If we consider democracy as a system inspired by the universalism of values typical of the West, can this be compatible with the values professed by Islam? Through some authors we have tried to understand if there can be compatibility and by virtue of this compatibility to establish a possible relationship with the West. This article analyzes in the light of this if there are paths within Islam that make a possible meeting. Hence the question: is it possible to discover another Islam that can weave its fates with democracy?
\end{abstract}

\section{Keywords}

Politics, Democracy, Islam

\section{Introduction}

At the end of the last century the democratization processes found their maximum expansion. This was expressed on a global scenario that did not spare even the most remote areas of the planet. In particular, the processes relating to the protection of constitutional values, typical of European and western culture, entered directly into the homes of millions of people, with important repercussions on the entire collective imagination.

The international public opinion, remained astonished by the significant shifts towards democracy occurring in purely authoritarian societies, including those that had been controlled by totalitarian regimes. After that wave of democratisation, the current scenario marked by economic crisis, financial capitalism, the effects of globalisation and glocalisation, alarming predictions are made about a democracy in crisis.

We wonder whether it is possible today to speak of democracy in Islamic contexts and, above all, whether the seed of democracy can take root in the lands of 
Islam.

In fact, talking about democracy in the Middle East today makes more sense than ever considering it has been through all sorts of violence and conflict. It can be an effective antidote, knowing that democracy requires the principle of conflict resolution. If this is the case theoretically, we need to understand whether all the conditions can be met at the socio-political level that will allow for its establishment and consolidation.

In this respect, to better introduce our article, it is important to re-propose a useful summary of the concept of democracy by letting guide and enlighten us, by those theories that for over thirty years preside over the most important analyzes on the processes of democratization at a global level. The Schumpeterian influence is decisive in affirming that idea of democracy founded on the supremacy of procedural universals, an idea that weakens all values such as "common good" and "popular will" and places an institutional configuration at the center of the democratic method aimed at achieving binding decisions, where the decision-making capacity of individuals is acquired in the electoral competition (Schumpeter, 1950).

In Schumpeter's view, a democracy can be considered as such when: the most important public offices are held through regular free and fair elections, when there is freedom to establish political organizations and freedom of expression, alternative sources of information and when the institutions make the government dependent on public election. Thus participation and contradictory, become crucial dimensions for democracy (Dahl, 1986), which becomes liberal in its essence and therefore characterized essentially by a set of recognized and pre-established rules capable of favoring political participation, unlimited competition and the peaceful resolution of conflicts and where the intermediate political structures play a decisive role in the structuring of the different interests and in the decision-making process (Morlino, 2008: pp. 25-26). Equally important is respect for these rules, so the question of legality becomes decisive and cannot be allowed to exercise de facto of certain powers on the part of forces such as the military or religious organizations. Moreover, it cannot include norms that give special powers to actors capable of conditioning public life through the limitation of certain aspects of the democratic method. There are still two elements that appear to be fundamental for a more exhaustive definition of democracy as underlined by Schmitter and Karl: the holders of directly elected public offices must be able to exercise their constitutional powers without being subject to the opposition (even informal) of those who, while holding public offices, they are not elected by the people, moreover, the polity must self-govern itself; it must be able to act independently from the limits imposed by any other superordinate political system (Schmitter \& Karl, 1993: pp. 45-46). Thus legality and independence become indispensable factors for the realization of a democratic regime. Often it has happened and continues to happen that despite the holders of public offices being democratically elected, they are not able to exercise a real power, because they are limited by other non-democratically 
legitimized groups, with which they must submit to or enter into compromise. When the decision-makers represent a pure the facade of the power, the system cannot be called democratic. Having clarified these aspects, this article is intended to be an analysis aimed at clarifying the key aspects of a possible democratisation in Islamic countries, with the help of contributions by now classic illustrious authors. However, please note that it does not claim to give solutions, but to humbly add some fuel for discussion.

\section{A Theoretical Perspective}

Democratic systems are struggling to establish themselves in Islamic countries and, where democracy is present, it is very weak, as in the case of Tunisia and Algeria or, with dangerous authoritarian regressions, as in the case of Turkey. What are the reasons that hinder the development of democracy? First of all, one has to ask whether the democratic method, briefly described above, can be applied in all contexts and what are the factors that guarantee grafting. A very wide and consolidated political science literature shows us how there is a strong correlation between economic system and political organization; Schumpeter, for example, defines modern democracy as the product of the capitalist process (Schumpeter, 1950: p. 297). Some have observed the impossibility of affirming political democracy in the absence of a market economy, specifying that the opposite is perfectly possible (Berger, 1992: p. 9). In a word, democracy requires the free market and, in the same way, a political culture that feeds on a specific conception of freedom capable of presiding over human and social interactions as a whole, of which freedom of worship is an integral part (Almond \& Powell, 1966). This aspect sheds light on the impossibility of the so-called export of democracy in contexts lacking an adequate political culture. Finally we limit ourselves to mentioning religious tradition as a vehicle for transitioning to democracy (Huntington, 1996). In this respect, much of the scientific literature considers the Islamic tradition to be unsuitable to favour the democratic process. The reasons can be identified in the almost total absence of the notion of political freedom in the people, where instead the idea of an organic community prevails, guided by spiritual beliefs and "revealed" immutable rules (Wright, 1992). This small excursus can be summarized and significantly represented with the notion of civilization, capable of giving an account of the democratization process in an evolutionary perspective. In the now classic book by Giovanni Sartori, Democrazia Cosa è (Democracy: What It Is), he starts from the following question: "Is it fair to say that Western civilisation is a superior civilisation?" I will tell you his answer in advance, which is "yes, it is fair to say so". But we must make it clear that it is an indiscriminate and therefore restricted yes, limited to the original meaning of the word civilisation, which is as abused today as it was unknown to the Enlightenment figures of the 1700s, who preferred the Latin etymology civis over it (Sartori, 2001: pp. 330-368). In fact, they spoke more specifically of civilité-civilisation-, meaning the particular ethical-political 
context into which Western society developed, which gave rise to the democratic-liberal-democratic-city, also known as good city.

If we stick to and just look at the ethical-political values that have emerged from Western culture, then we can rightly acknowledge that the West is where the first free city was erected. It is a good city, as it "established the city of citizens in place of the city of subjects" (Ivi, 332).

Therefore, while, generally speaking, ranking civilisations from superior to inferior does not make much sense as now the word civilisation is an all-encompassing term of a cultural nature from which it is really difficult to see the general picture, Sartori's idea that the West is superior is quite strong, when it comes to a comparison between civilisations. In fact, whoever would go so far as to question such an idea would inevitably shift the focus onto an axiological level. It is not that the author hides the fact that the primacy of the "good city" is based on value-related principles. However, he specifies that we can only reflect on the universality of values effectively by making two preliminary observations.

The first one involves taking a preliminary step back from multicultural theories, according to which all values are equal, hence no one is worth more than the other. In reality, these theories are incorrect, since they may result in an axiological relativism which, taken to its extreme consequences, would be self-destructive.

The second one refers to the theoretically valid idea that, given the premise that the values have a rational basis, their superiority could be rationally proven. However, because the basis of values is undoubtedly emotions, it is more reasonable to wonder whether to favour some over others: "which implies that the values are validated by comparison, comparing them" (Ivi, 333).

This is even more necessary if we consider that, in spite of the universal rights proclaimed by the Universal Declaration of Human Rights of the United Nations, which refer to equally universal values, this document was never ratified by most Islamic countries.

But-Sartori adds-to go further and search for "superior" values in the sense of "preferable" values, two conditions are necessary: first, in order to analyse "comparative preferences" to make a choice, we would need to be sure that the people we are addressing are able to compare the things to choose from, since it is impossible to ascertain the preferences of those who have never had any alternatives. Furthermore, we would need to reformulate typical, highly abstract Western concepts in concrete terms, such as "freedom", significantly taken as an example by the author.

Given these conditions, we may wonder, in the case of freedom, meaning concretely safeguarding one's own survival, whether there are people in this world who prefer to live in the uncertainty that they can die at any moment, who prefer the uncertainty of their daily life over safety.

Well, from this point of view, one can easily assume that everybody would choose to live a life free from such uncertainties. Consequently, freedom as "living safely" is certainly a universal value, in the sense of a "feeling of common 
value" for all men (Ivi, 335).

\section{From Universality to Universalism of Western Values}

It is quite different to claim that Western culture is superior to all others if by superiority we mean an idea of the world relating to a way of life which implies a conceptual aggregate as varied as it is impossible to compare. What would such a statement be based on? And what would the benchmark be?

Therefore, it would be easy and even quite fair to accuse those who claim that Western culture is superior to others of being arrogant, especially from the point of view of other cultures which, the more they develop self-confidence, the less they are fascinated by ours.

In fact, as the relative power of non-Western peoples grows stronger, whether due to the impetuous economic rise of the Sinic civilisation or to the strong demographic growth of the Islamic one, the efforts made by the West to propagate its values as universal achieve increasingly less appreciable results.

This is especially so because non-Western populations accuse the West of imposing its own values, misleadingly identifying them with those of the international community, in order to defend its interests. Additionally, non-Westerners accuse Westerners of applying double standards: for example, Muslims point out that the principle of non-proliferation of arms is valid for some countries but not for Israel, or that free trade-as the Chinese claim-is considered the engine of economic development, but not in the agricultural sector.

That being said, the diversity of cultures is such that it effectively counteracts those who persist in giving universal importance to Western civilisation; in fact, that which for Westerners is universalism of values, for non-Westerners is often, much more simply, imperialism, and not just in terms of values.

So, in the emerging world of increasingly persisting ethnic conflict, Western belief in the universality of Western culture suffers three problems, as summed up well by Michael Howard: it is false, it is immoral and it is dangerous.

With regard to the first point: "The common Western assumption that cultural diversity is a historical curiosity being rapidly eroded by the growth of a common, western-oriented, Anglophone culture [...] is simply not true" (Howard, 1984: p. 6).

In addition to this, the belief that non-Western peoples should adopt Western values, institutions and culture is immoral because of what would be necessary to bring it about. Obviously, the almost-universal reach of European power in the late nineteenth century and the global dominance of the United States in the late twentieth century spread much of the Western civilisation across the world. If European universalism ever existed in the past, it no longer applies to the present, nor to the future. On the contrary, if non-Western societies are once again to be shaped by Western culture, it will happen only as a result of the expansion, deployment and impact of Western power, as power is what culture is based on, as we have seen. 
In fact, and this is the most important aspect, the assumed Western universalism is dangerous, or it could be dangerous if it were to continue to be extended, because it would only exacerbate the conflicts between the West and the others. If this were to happen, then all of Samuel Huntington's exhortations would have led to nothing.

I would like to take a moment in this regard, firmly disproving the opinion of those who have hastily read The Clash of Civilizations (Huntington, 1996). Although the author certainly understands that this may be a possibility-which in some ways is in fact already a reality-he is absolutely not theorising it, even if that which has been written could be prejudicially assumed to be as such, and something which the author ultimately desires.

In fact, despite the gap between the different civilisations, their clash-warns Huntington-is still avoidable, under two conditions: that "understanding and cooperation among the political, spiritual, and intellectual leaders of the world's major civilizations" prevails, and that the foundations are laid for the construction of "an international order based on civilizations", which remains the surest safeguard against a new world war (Ibid.).

\section{Which democracy for Islam}

In the introduction to the highly evocative book L'Islam è compatibile con la democrazia (Is Islam compatible with democracy?), Guolo asks the definitive question:

"Is Islam really compatible with democracy? And, given that this political contamination is sought after by the Muslim world, what kind of democracy can be exported around the world? A democracy understood as a mere electoral process or broadening of political participation; or instead as a political, legal, cultural, and social fabric, made up of individual and collective rights, gender equality, separation of powers, pluralism, affirmation of positive law? An illiberal democracy or a liberal democracy, to use categories argued by Fareed Zakaria? As for the first one, there do not seem to be any insurmountable obstacles [...]. But without the widespread internalisation of the cornerstones of liberal democracy, there is the very high risk that such a cultural and political context gives rise to 'democracies without democrats'. Also, under the dominion of the 'tyranny of the majority', new forms of authoritarianism can be established in the absence of institutions of guarantee and, above all, of a political culture that feeds them" (Guolo, 2007: p. VIII).

No one could deny that a mere electoral process, in a context where liberal and democratic values are still unknown-as is the case today in most Muslim countries-may produce "democracies without democrats" due to the "tyranny of the majority". Of course, free elections are the founding moment of a democratisation process, as they give shape to the decisions made through popular sovereignty. However, without the creation of a system of government with checks and balances-that is, without a constitutional system of rule of law-elections alone are not enough. They are therefore necessary to start on the 
path of democratic transition, but not enough on their own.

In fact, the electoral mechanism acquires a democratic value only if it is part of a system made democratic by institutions that limit arbitrary power. These are the only ways to prevent a tyrant from coming out of the elections as the winner, who would then keep those who allowed him to win in subjection.

Therefore, in the absence of a broader liberal culture and practices, the electoral route alone risks in any case to legitimise old and new undemocratic regimes. While it is true that democracy is a procedure, a method, it is also true that, for it to be real, it must be able to exclude any totalitarian principle from politics, which in turn prevents the different political alternatives from competing freely against each other. In this sense-says Guolo-democracy "is the absence of a community, which is undifferentiated, organic and unite around the God of Devotion as well as the God of Politics". Therefore-the author continues-"the acquisition of an institutional model is not sufficient to ensure the introduction of democracy. Especially if that internalisation does not occur over a long process [...], but is the product of external pressure only, perhaps of a military nature. Poverty, poor education, authoritarianism and limitation of freedoms, gender inequalities, holism, lack of secularisation and privatisation of the religious sphere, are among the causes that make it difficult for democracy to be internalised by the Islamic world [...]. In order for democracy to be established [then], the Muslim world needs an economic boom that allows the modernisation of society, favouring the formation of a varied social context in which classes put an end to their dependence [...] from rulers [...], by taking advantage of the market and freedom as well. Only this mix of institutional change, freedom, education and liberation from need can allow the Islamic world to address issues such as the conception of religion as a source of law, codified gender inequality, the incorporation of the traditional regulatory hierarchy 'religion-society-state', the full delegation to the political power and the absence of balancing powers and guarantees" (Ivi, 134-135). Having made this first, basic distinction between illiberal and liberal democracy, it is necessary to examine in depth the constituent characteristics of the latter, in order to be able to answer the question of whether it could be exported.

It is to this end that I am obliged to resort again to the contribution of Sartori who answers: "...yes [democracy is exportable]; but not everywhere and not always. And the preliminary point remains which of its constituent parts are exportable, or more exportable. In this view, the concept of liberal democracy must be broken down into the two elements it is made of-liberal and democratic. The liberal component is 'liberating': it sets the demos free from the oppression of servitude and despotism. The democratic component is, instead, 'empowering' in the sense that it strengthens the demos. The above can therefore be rephrased as follows: liberal democracy is first of all demos-protection, the protection of the people from tyranny; and, secondly, demos-empowerment, the attribution to the people of quotas, and also increasing quotas, of the actual exercise of 
power" (Sartori, 2001: pp. 339, 340).

It should be noticed how the author has positioned the two terms in his sentence: he speaks of "demos-protection" first, and then of "demos-empowerment". This is not to decide-as Sartori himself specifies-which of the two elements of liberal-democracy is more important. Rather, it is useful to verify which of the two comes first. In this sense, a priority exists and is also very clear-cut. In fact, without demos-protection, there can be no demos-empowerment; in other words, first people must be free "from", otherwise they cannot be free "to". Indeed, if people are not yet "citizens" but remain "subjects", meaning they are not free from political oppression, how can they be free to express their opinions, join other people, vote, etc...?

Therefore, the necessary condition for a liberal democracy to take place is the liberal part of it. This statement has two important consequences: firstly, although being important, demos-empowerment-as a definition of the contingent characteristics existing to a varying extent in a liberal democracy-cannot replace demos-protection. And secondly, demos-protection-as representing a minimum definition of democracy-also proves itself to be an essential definition.

It is therefore the second meaning of the term "democracy" that Sartori refers to when he speaks of it being exportable. In fact, since demos-protection is the minimum fundamental requirement of liberal democracy, "as a result it should also be its universal element or, in any case, the most universalisable and easiest to export" (IVi, 341). As demos-protection represents a set of institutions and methods for limiting and controlling public authorities -the how to proceed-without previously establishing the content of political decisions-the what to decide-then it should be easily exportable.

In any case, the export of democracy understood as a "form" of State-the constitutional government-and not as a "substance" of State, can be the result either of an endogenous transformation of the political and institutional structures or of a military defeat, as happened in Italy, Germany and Japan at the end of the Second World War.

However, Japan is the truly exemplary case of these three.

Before the advent of each period of dictatorship, Italy and Germany were already quite socially differentiated, and rule of law was in its infancy, with political and cultural pluralism and an electoral process with a democratic nature.

In Fascist Italy, which had previously been through the resurgence and the era of Giolitti, the historical anti-fascist liberal, Catholic and socialist components had been repressed or marginalised, but they had remained deep rooted throughout the twenty years of Fascism. During the civil war, along with the liberation war against the Nazi enemy, the plural orientations within the Cnl (National Liberation Committee) demonstrated the existence of a political and social substratum that had not been completely eroded by fascism, which proved fundamental to the taking back of the democratic institutions. 
As for Nazi Germany, preceded by the Weimar Republic, social democracy had played a similar role to that of our Liberation Committees-although still different from that experienced in Italy.

Instead, Japan was a very different case, not only because of its clear cultural heterogeneity and the presence of a society with a certain degree of holism, but also because of the long American occupation, which was undoubtedly decisive for the consolidation of future democracy.

However, having said that we must not forget that Japanese culture, so to speak, "was suitable for transplant". First of all, as a result of modernisation during the Taisho era which had created a context of relative political and social pluralism. Furthermore, the industrialisation of the country had itself encouraged the formation of a labour movement that-although not comparable to the Italian or German ones-had attained significant social achievements, including in terms of civil rights. Second of all, because-as Sartori points out-when General MacArthur arrived, the Japanese were governed by the Emperor, who successfully ordered his subjects to indulge the American proconsul (Ivi, 342). Finally, in Japan there has never been an obstacle similar to that represented by monotheistic religions, which were an essential element.

Thus, the endogenous religious pluralism represented by the coexistence of Shintoism and Buddhism-both non-dominant and non-invasive cults-has undoubtedly favoured the process of Japanese democratisation, as well as its consolidation.

In this way, the Japanese case shows that democracy is by no means intrinsically linked to the Western cultural system, as Japanese society was able to appreciate Western governance methods, while not rejecting its own origins and traditions.

However, Sartori mentions an even more striking and significant example than Japan: India. During the long British colonial rule (1813-1947), India had the opportunity to become familiar with typically Western concepts and institutions, such as constitutionalism, liberal democracy and methods of parliamentary government, which it would then acquire and maintain. Nevertheless-and here is the core issue-, in this country the religious obstacle was a much more serious and complex problem than in the Japanese case.

The most widespread Indian religions are, in fact, in order: Hinduism, Buddhism and Islam. Today, Hinduism defines the traditional and cultural identity of the country, it includes elements of nationalism and therefore has not always been peaceful. But it is also a pantheistic and strongly syncretic religion. Buddhism is about introspection and meditation. So, it does not pose any particular problem for the establishment of democratic institutions. "Problems which-according to Sartori-are instead irreducibly created by Islamic monotheism. So much so that when the Englishmen left, they had to resign themselves [...] to dismember India, creating an Islamic territory that would in turn be divided into two states: Pakistan and Bangladesh. Here it is important to underline-continues the author-that first, had this not happened, India would 
have risked being torn apart, despite a thousand years of coexistence, by a terrible civil war. And second, the reason why India is a democracy is because the Islamic obstacle was largely removed as a consequence of the partition of the country" (Ivi, 160).

Therefore, India, as well as Japan, proved that a certain cultural heterogeneity does not prevent-indeed can help to promote-the creation of a Western-like democracy. India, in fact, is another example of "imported" democracy, without even renouncing its native culture. From the observations made so far, we can reasonably infer that "religion is not an obstacle if and when it can accept the secularism of politics [...]. To sum up-concludes Sartori-it is not true that constitutional democracy, especially in its essence as a system of demos-protection, cannot be exported/imported outside the context of Western culture. But monotheistic religions may be an obstacle to embracing it" (Ivi, 343).

\section{Christianity, Islam and Secularism}

By way of principle, both Christianity and Islam are theocratic societies, as they are both based on the will of God and the obedience to God. Moreover, they are both strong religions, as they are monotheistic-that is, based on faith in a single God-and totalitarian religions, both requiring the absolute submission of the believer. Therefore, given these characteristics, they are intolerant per se, as they forbid apostasy and persecute heresy. And finally, they are strong religions also because they are invasive, as they are against non-believers and all worshippers of false idols. For this reason, over a long period of time, lasting approximately from the seventh to the twelfth century, the conflict between Christianity and Islam has historically appeared as a war between two religions and, therefore, as a "war of religion". However, since 1600s, European society has progressively secularised, and its Christian identity has gradually weakened: less and less will it be referred to as "Western Christianity", as a shift is made to its referral as "Western Civilisation" (IVi, 343-345).

On the contrary, Islam has remained a "theocratic civilisation" over time: hence, the so-called "clash of civilisations", "between" civilisations. However, it is an asymmetrical conflict, with the secular West on one side facing religious Islam on the other. This indicates that while the former has long since abandoned the spirit of world propaganda of the faith that had supported its expansionist aims in the past, the latter, on the contrary, still aspires to spread the Truth revealed to Mohammed on a world scale. It is not only a conflict of civilisations though, but also and still-and Sartori is right in pointing this out-a war of religion. However, even if the antagonists are on the one hand a religion and on the other a non-religion, it does not alter the substance of the conflict. That being said, where do such profound differences stem from? Having asked himself this question, which is as vast as it is difficult, Sartori provides two brief, simple and clear explanations, yet extremely detailed, which go straight to the 
heart of the problem:

1) Paradoxically, the West was secularised by extremely bloody religious wars that had no precedent in the history of Islam: notably, the war between Catholics and Protestants. Europe came out of it so damaged that it asked for and obtained not only religious tolerance, but also-more generally-respect for dissent, understood as concordia discors or at least as discord turned into concord.

2) Although, both Christianity and Islam as such are two strong religions, the former has always historically proved less strong than the latter, for two reasons. First of all, because Christianity was superimposed on the previous Roman civilisation, without ever usurping its juridical sphere. In fact, canon law is an internal law of the Church, while European law remained, in its general structure, Roman and therefore autonomous. On the contrary, Islamic law has always been constitutionally dependent on Quranic law.

Secondly, because Christianity never appeared as an armed religion having characteristics similar to those which have made Islam a "religion under arms". As a matter of fact, the Crusades were fought "by proxy", by feudal lords and sovereigns who, rather than annihilating the infidels, were aiming to take Jerusalem away from them and give the "Holy Land" to Christianity.

Moreover, it can be said in general that the "power of the sword" was never directly the Holy See: it would instead be more correct to affirm that, from time to time, it "lent" to it (Ibid., 345-354). Therefore, if the Papacy never had real armies, the same is true for Islam which, in little more than a century from the Revelation, had conquered all of North Africa, a good part of Spain, as well as the Indian territories and all the way up to the Balkans, before being stopped in Vienna (1683). This was the first real defeat of the Ottomans, who then had to partially surrender to the Tsarist Russia (1774) and totally to the conquest of Egypt (1789-1801) by Napoleon.

Through these two explanations, Sartori wants to demonstrate that Islam has been, since its origins, stronger and more resistant than Christianity. The latter, in fact, was historically formed on a previous cultural and civil Greek-Roman substratum never completely abandoned, even in the late Middle Ages. Instead, from the Renaissance onwards it has re-emerged with determination, allowing for the secular revival after the Reformation which established the principles of tolerance and pluralism.

The birth of liberal constitutionalism was possible because of these premises, as it was based on the separation between politics and religion and on the rejection of any and all monocratic powers. Hence the triumph of individual freedoms, on the one hand, and the principle of democratic legitimacy of power on the other.

Of course, this would be generalising, as Sartori candidly admits. The West has never been completely secularised, just as Islam-as we have seen many times. This said, it does not have an undifferentiated aggregate within it.

There is no doubt that there is no authentic Islam, but rather a varied and dy- 
namic Islamic reality, at least as much as its sacred text which is devoid of precise meaning and can therefore be interpreted personally.

However, although there is no "true" Islam, there is no guarantee that there is no predominant or even winning Islam, which the author identified with radical Islamism. "This does not mean that radicalism is the majority, though it certainly is the one that stands out, despite the number of extremist affiliates. And in any case," adds Sartori, "It is mass Islam itself that keeps a strict and inflexible position in response to the cultural assault coming from the West, contrary to what the conciliatory Indian and Japanese civilisations do, and China is beginning to do. As a result - in the case of Islam-the more the secular West believes to be on a mission to liberate Islam by forcing it into democracy, the more the latter believes it must react by counterattacking the missionary West".

Finally, Sartori mentions the problem of the relationship with Islamists who have immigrated to Europe, referring to another of his writings for a more in-depth analysis of the subject. However, he does not fail to mention what is at the heart of this further aspect of the debate, and I too believe it is right to refer to what he has said because, in my opinion, his words may be generalised, at least in part.

The point-according to Sartori-is whether the Islamist-I would have preferred the more neutral term Muslim-can be integrated into the secular city. Sartori is right in saying integrated, rather than assimilated, as the Indians, Japanese and Jews, far from letting themselves be assimilated, all retain their original identities, without becoming unwanted citizens in the West. "Islam, on the other hand, does not-as the author cuts short-. Its culture, as Toynbee puts it, lacks flexibility, it is a rigid culture that feeds and defends itself by closing itself off [...]. This is because for Islamists, faith is the ultimate root, if not the only one, of his own identity" (Ibidem).

\section{Conclusion}

\section{Discovering another Islam}

In opposition to scholars who are sceptical about the democratic transformation of Islamic societies and political institutions, there is a group of authors-in truth, much less numerous-who are convinced not only that there is compatibility between Islam and democracy, but also, rejecting the hypothesis of an original conflict between Islam and the West, that Islamic radicalism, far from constituting the essence of Muslim religious tradition, actually is a deviation caused by history.

It is important to understand if their interpretations, which are certainly based on theoretical foundations, can contribute to a renewed debate on the possible democratisation of Islam, beyond the annoying media rhetoric which, in my opinion, does nothing but confuse ideas.

For example, Bernand Lewis firmly argues that Islam is not irreconcilable with Western-like democratic and liberal institutions, in the sense previously ex- 
plained by Sartori. According to the Princeton historian, in fact, if it is true that in Muslim tradition there have never been real elements of democratic government, it is also true that there are contractual and consensual forms of government-with the shûra, enshrined in Quran rules-which can favour the progressive internalisation of democracy.

In particular, to those who believe that there is a close link between Islam and authoritarianism, Lewis replies that it is not Islam as such that has favoured the idea of an exclusive power. Instead, it was allegedly the political changes induced by modernisation that produced the undue extension of the traditional tasks of the caliph, thus making the traditional principle of consultation of secondary importance.

According to him, in fact, in the past, Muslim governments were relatively autocratic. On the contrary, the excessive expansion of political power was caused by the secular and modernising Islamic dictatorships supported by movements inspired by the model of the extremist mass parties that took root in the West from the first half of the $20^{\text {th }}$ century. The application of the Western-like authoritarian model would then cause drastic political transformations in Muslim countries, such as the strengthening of leaders' powers along with a decrease in the influence of political and social components which, traditionally, limited their power; among these, the ayans, similar to notable figures who used to represent the public opinion of the most socially relevant groups.

In summary, Lewis asserts that the radical drift of contemporary Islamism is not the inevitable product of Islam per se, but rather the contingent consequence of the lack of modernisation of Muslim countries. "Almost the entire Muslim world is affected by poverty and tyranny [...]. The Middle Eastern combination of low productivity and high birth rate makes for an unstable mix, largely and increasingly composed of unemployed, ignorant and frustrated young people. By all indications of the United Nations, the World Bank and other authorities, the Arab countries [...] lag ever farther behind the West. Even worse, the Arab nations also lag behind the more recent recruits to Western-style modernity, such as Korea, Taiwan, and Singapore" (Lewis, 2004: p. 103).

In addition to what has been said, the historian says that, if possible, political modernisation has had even more harmful consequences than economic and even military modernisation.

"Many Islamic countries have experimented with democratic institutions of one kind or another. In some [...], they were introduced by innovative native reformers; in others, they were installed and then bequeathed by departing imperialists. The record, with the possible exception of Turkey, is one of almost unrelieved failure. Western-style parties and parliaments almost invariably ended in corrupt tyrannies, maintained by repression and indoctrination. The only European model that worked, [...] was the one-party dictatorship [...]. Since the death of Nasser, in 1970, no Arab leader [...] has been willing to submit his claim to power to a free vote".

According to Lewis, Muslim peoples-and in particular those in the Middle 
East-have become increasingly aware of the deep and widening gulf between the opportunities of the free world outside their borders and the appalling privation and repression within them. The resulting anger is naturally directed first against their rulers, and then against those whom they see as keeping those rulers in power for purely economic interests. "It is surely significant that most of the terrorists who have been identified in the September 11th attacks on New York and Washington come from Saudi Arabia and Egypt-that is, from countries whose rulers are deemed friendly to the United States.”

As François Burgat also summed up well: "In the aftermath of independence, the social strata held back from accessing to the benefits of modernisation resorted to the vocabulary of Islam, and used it (initially but not exclusively) to express (against or, if necessary, after the State) a political project that would harness Western legacy, but authorizing this through its re-approval" (Burgat, 1995).

Due to this background and the current importance given to Islamic radicalism, the creation of democracy in the Middle East as a consequence will neither be quick nor easy, even less than it was in Europe or America. In the Middle East this must be done gradually, too. Pushing too far and too fast would give an immediate advantage to those who use the weapons of manipulation and assumed hegemony. The above is confirmed by the example of the so-called "Arab Spring", whose outcome was disastrous, with the exception of Tunisia, which may be the breeding ground for new protests again. It has greatly contributed to new and persistent waves of violence, civil wars, as in Syria, and the return of authoritarianism, as in Egypt. In definitiva, non ha di certo rappresentato un anelito di libertà e democrazia mostrando una matrice confessionale e non civica (Adonis, 2015).

Therefore, in a context of high social tensions, shaky institutions and general malaise experienced by growing masses of marginalised Muslims, an ideology formulated in Islamic terms could offer several advantages: a basis for group identity and solidarity; an acceptable foundation of legitimacy and authority; an immediately understandable formulation of the principles on which to base criticism of present and future plans. In this sense, Islam is able to provide the most convincing symbols and slogans to mobilise the masses for, or against, a cause or a regime. The risk is moving further away from the democratic ideal though.

But Islam is not just about that, actually it is predominantly not about that.

\section{Conflicts of Interest}

The author declares no conflicts of interest regarding the publication of this paper.

\section{References}

Adonis (2015). Violence et Islam. Paris: Éditions du Seuil.

Almond, G. A., \& Powell, G. B. (1966). Comparative Politics: A Developmental Ap- 
proach. Boston, MA: Little, Brown and Company.

Berger, P. (1992). The Uncertain Triumph of Democratic Capitalism. Journal of Democracy, 3, 7-17. https://doi.org/10.1353/jod.1992.0046

Burgat, F. (1995). L'islamism au Magreb. Paris: Payot.

Dahl, R. A. (1986). Procedural Democracy. In R. Dahl (Ed.), Democracy, Liberty, and Equality. Oslo: Universitetsforlaget.

Guolo, R. (2007). L'Islam è compatibile con la democrazia? Roma-Bari: Laterza.

Howard, M. (1984). The Military Factor in European Expansion. In H. Bull, \& A. Watson (Eds.), The Expansion of International Society. Oxford: Clarendon Press.

Huntington, S. P. (1996). The Clash of Civilizations and the Remaking of World Order. New York: Simon \& Schuster.

Lewis, B. (2004). La crisi dell'Islam. Milano: Mondadori.

Morlino, L. (2008). Democrazie fra consolidamento e crisi. Bologna: Il Mulino.

Sartori, G. (2001). Democrazia cosa è. Milano: Rizzoli.

Schmitter, P. C., \& Karl, T. (1993). What Democracy Is... and Is Not. In L. Diamond, \& M. Plattner (Ed.), The Global Resurgence of Democracy. Baltimore, MD: The Johns Hopkins University Press.

Schumpeter, J. A. (1950). Capitalism, Socialism and Democracy. New York: Harper and Row.

Wright, R. (1992). Islam and Democracy. Foreign Affairs, 71, 131-145.

https://doi.org/10.2307/20045234 